\title{
1 Genomic network analysis of an environmental and livestock IncF
}

\section{2 plasmid population}

4 William Matlock ${ }^{1}$, Kevin K. Chau ${ }^{1}$, Manal AbuOun ${ }^{2}$, Emma Stubberfield ${ }^{2}$, Leanne Barker ${ }^{1}$, James

5 Kavanagh $^{1}$, Hayleah Pickford ${ }^{1}$, Daniel Gilson ${ }^{2}$, Richard P. Smith ${ }^{2}$, H. Soon Gweon ${ }^{3,4}$, Sarah J. Hoosdally ${ }^{1}$,

6 Jeremy Swann ${ }^{1}$, Robert Sebra ${ }^{5}$, Mark J. Bailey ${ }^{3}$, Timothy E. A. Peto ${ }^{1,6,7}$, Derrick W. Crook ${ }^{1,6,7}$, Muna F.

7 Anjum $^{2}$, Daniel S. Read ${ }^{3}$, A. Sarah Walker ${ }^{1,6,7 *} /$ Nicole Stoesser $^{1,6,7 *} /$ Liam P. Shaw $^{1 *}$, and on behalf of the

$8 \quad$ REHAB consortium ${ }^{\dagger}$

$9 *$ contribution considered equal

$10 \dagger$ see acknowledgements

$11{ }^{1}$ Nuffield Department of Medicine, University of Oxford, Oxford, UK

$12{ }^{2}$ Animal and Plant Health Agency, Weybridge, Addlestone, UK

$13 \quad{ }^{3}$ UK Centre for Ecology \& Hydrology, Wallingford, UK

$14 \quad{ }^{4}$ University of Reading, Reading, UK

$15 \quad{ }^{5}$ Icahn Institute of Data Science and Genomic Technology, Mt Sinai, NY, USA

$16 \quad{ }^{6}$ NIHR HPRU in healthcare-associated infection and antimicrobial resistance, University of Oxford, Oxford, UK

$17{ }^{7}$ NIHR Oxford Biomedical Research Centre, University of Oxford, Oxford, UK

18 Correspondence: William Matlock (william.matlock@ndm.ox.ac.uk) and Nicole Stoesser (nicole.stoesser@ndm.ox.ac.uk)

Keywords. plasmid genomics; Enterobacteriaceae; environmental bacteria; antimicrobial resistance (AMR);

21 network analysis; One Health 
bioRxiv preprint doi: https://doi.org/10.1101/2020.07.24.215889; this version posted July 24,2020 . The copyright holder for this preprint (which was not certified by peer review) is the author/funder, who has granted bioRxiv a license to display the preprint in perpetuity. It is made available under aCC-BY 4.0 International license.

\section{Abstract}

24 IncF plasmids are diverse and of great clinical significance, often carrying genes conferring antimicrobial resistance (AMR) such as extended-spectrum $\beta$-lactamases, particularly in Enterobacteriaceae. Organising this plasmid diversity is challenging, and current knowledge is largely based on plasmids from clinical settings. Here, we present a network community analysis of a large survey of IncF plasmids from environmental (influent, effluent, and upstream/downstream waterways surrounding wastewater treatment works) and livestock settings. We use a tractable and scalable methodology to examine the relationship between plasmid metadata and network communities. This reveals how niche (sampling compartment and host genera) partition and shape plasmid diversity. We also perform pangenome-style analyses on network communities. We show that such communities define unique combinations of core genes, with limited overlap. Building plasmid phylogenies based on alignments of these core genes, we demonstrate that plasmid accessory function is closely linked to core gene content. Taken together, our results suggest that stable IncF plasmid backbone structures can persist in environmental settings while allowing dramatic variation in accessory gene content that may be linked to niche adaptation. The recent association of IncF plasmids with AMR likely reflects their suitability for rapid niche adaptation.

Introduction

Environmental (non-clinical, non-human) populations of Enterobacteriaceae may act as a genetic reservoir for antimicrobial resistance (AMR). This includes livestock [1-5] and water-borne [6] resistance. Frequent horizontal gene transfer (HGT) in Enterobacteriaceae populations results in a large and open pangenome, enabling the wide-spread transmission of the genes conferring AMR [79]. This includes AMR transmission between humans and the environment and vice versa [10]. However, evidence for this transmission is often context and sequence type (ST)-specific, with broader transmission patterns less conclusive [10, 11]. IncF plasmids are a diverse group of

49 Enterobacteriaceae-associated replicons which mediate the transfer of AMR genes. They have also 
bioRxiv preprint doi: https://doi.org/10.1101/2020.07.24.215889; this version posted July 24,2020. The copyright holder for this preprint (which was not certified by peer review) is the author/funder, who has granted bioRxiv a license to display the preprint in perpetuity. It is made available under aCC-BY 4.0 International license.

51

particular, their involvement in the dissemination of genes encoding extended-spectrum $\beta$-lactamases (ESBLs), such as bla-CTX-M-15, is of major clinical concern [13, 14], and almost $40 \%$ of plasmid-borne carbapenemases are carried on IncF plasmids [15]. IncF plasmids are often low copy-number and conjugative [16]. Further, recent database analysis suggests IncF alleles are carried in over $50 \%$ of multireplicon plasmids [12].

Previous studies of IncF plasmids have often focussed on clinically relevant isolates, often only those encoding ESBLs [15]. Further, they have been limited to studies with smaller sample sizes. Here we analyse hundreds of IncF plasmids drawn from a survey of environmental diversity in

Enterobacteriaceae, sampled in 2017 from a region of south-central England, UK [17]. Sampling was from livestock (cattle, pig, sheep), and from influent, effluent, and upstream/downstream waterways surrounding wastewater treatment works (collectively termed WwTWs). Potential seasonal variation was accounted for by sampling over three time-points at each site. This provided a high-quality dataset of $n=726$ plasmids for characterising natural plasmid populations.

Frequent co-integration and HGT events mean plasmid evolution cannot be described with a phylogenetic tree. Instead, networks based on sequence similarity can be used [18]. In such networks, nodes represent plasmids, and edges are weighted by a metric on the plasmid sequences. This captures both vertical and horizontal evolution at the cost of not providing a most recent common ancestor. Communities are a topological property of networks. They are defined as subsets of nodes with dense intra-connections, but sparse inter-connections [19]. In our analyses, they represented groups of similar plasmid sequences. Detecting these structures gives a coarse-grained view of the plasmid population. Previous efforts have often focussed on the relationship between network features used in plasmid classification schemes, such as replicon presence, MOB-type, or predicted mobility [20-23]. Further, studies have often focussed on curated selections from online databases [20, 22-24]. It is yet to be seen if similar community structure is present in large-scale natural populations. Additionally, it is important to develop fast and scalable methods for analysis of large and diverse WGS datasets.

Here we aimed to provide a framework applicable to such studies. 
80 Results.

A natural population of complete plasmids with IncF replicons.

We recovered $n=726$ circularised plasmids containing an IncF replicon (see Table S6) from a large dataset of high-quality Enterobacteriaceae genomes, obtained by hybrid assembly using both shortread (Illumina, 150bp paired end) and long-read (PacBio or Nanopore) sequencing of cultured isolates [17]. These isolates were collected over three time-points in 2017 from a region of south-central England, UK. Sampling was from 14 livestock farms (4 pig, 5 cattle, 5 sheep) and from waterways (influent, effluent and rivers) surrounding five WwTWs. Of the livestock plasmids, 120 were from pigs, 137 were from cattle and 150 were from sheep. The remaining 319 plasmids were from WwTWs.

IncF plasmids were found across all four genera in the dataset: Citrobacter (53 C. freundii), mostly came from Escherichia (392/407), whereas WwTW plasmids had a more uniform distribution over all four genera in line with the greater diversity of genera in WwTW isolates (Fig. 1a). Our plasmids originated from $n=558$ host Enterobacteriaceae isolates, with a majority of chromosomes circularised (431/558).

Plasmids ranged in length from approximately $20 \mathrm{~kb}$ to $480 \mathrm{~kb}$ (Fig. 1b). A majority of plasmids were

100 predicted to be conjugative (516/726), with a smaller number predicted to be mobilisable (39/726) or 101 non-mobilisable (171/726) (see Materials and Methods). Plasmid length was linked to mobility, with conjugative plasmids generally larger than mobilisable and non-mobilisable plasmids (Kruskal-Wallis test $[H=36.7, p=1.08 \mathrm{e}-8]$ followed by Dunn test with Holm adjusted $p$-value [Conj-Mob: $Z=3.45, p$ value $=1.14 \mathrm{e}-03$; Conj-Non-Mob: $Z=5.39, p$-value $=2.07 \mathrm{e}-07$; Mob-Non-Mob: $Z=-0.54, p-$ value $=0.59])$. We found 25 different replicons across all plasmids, including 11 in unspecified gene clusters, present in 62 different combinations or 'replicon haplotypes' (Table S1). 28 replicon 
bioRxiv preprint doi: https://doi.org/10.1101/2020.07.24.215889; this version posted July 24,2020. The copyright holder for this preprint (which was not certified by peer review) is the author/funder, who has granted bioRxiv a license to display the preprint in perpetuity. It is made available under aCC-BY 4.0 International license.

107 haplotypes appeared only once in the sample. Plasmids carried between 1 and 5 replicons, with a

108 majority carrying $2(318 / 726)$ or $3(209 / 726)$. Plasmid length was positively associated with number

109 of replicons carried (one-way ANOVA test $[F(4,721)=5.64, p$-value $=1.8 \mathrm{e}-4]$ followed by Tukey's

110 HSD). All plasmids contained at least one IncF replicon: IncFIA (147), IncFIB (460), IncFII (574)

111 and IncFIIA (370). Of the remaining replicons, IncI1 was most common (28), and was always found

112 with an IncFII replicon. We observed different replicon co-occurrrence patterns (Fig. 1c), with

113 individual IncF replicons associated with different non-IncF replicons. For instance, IncU and IncN

114 replicons were only found with IncFIB and IncFII respectively. Overall, these co-occurrence patterns

115 corroborate previously observed patterns of frequent IncF association with replicons such as IncI1,

116 IncX and IncR [12].

118 IncF plasmids tended to be AT-rich relative to their host chromosomes. This trend has been widely 119 reported before $[25,26]$. However, we found that relative AT-richness significantly varied between 120 host genus (one-way ANOVA test $[F(3,561)=111, p$-value $<2 \mathrm{e}-16]$ followed by Tukey's HSD), 121 independently of average host GC-content, with Klebsiella plasmids having a greater relative AT122 richness than other Enterobacteriaceae plasmids (Fig. 1d).

Detecting communities in plasmid k-mer networks.

125 Plasmid sequence distances were calculated using MASH, a $k$-mer based distance estimation [27] (see

126 Materials and Methods), and these distances used as weighted edges in a plasmid network. The output

127 MASH edge list is presented in Table S7. Communities were detected using the Louvain algorithm,

128 which optimises the modularity of the networks, and is a weighted community detection algorithm,

129 meaning it also accounts for the MASH distances [19]. To effectively detect communities, we reduced

130 the density of the network by thresholding the edges (i.e. by 'sparsification'). Fig. 2a-b shows how the

131 number of identified communities and percentage of plasmids covered changed as the edge (i.e.

132 MASH distance) threshold was varied. Generally, the Louvain algorithm became more consistent in 133 coverage as we sparsified. To ensure the communities represented potential sub-populations, we only

134 considered those with at least 10 plasmids. The large drop in community coverage seen at 
bioRxiv preprint doi: https://doi.org/10.1101/2020.07.24.215889; this version posted July 24,2020. The copyright holder for this preprint (which was not certified by peer review) is the author/funder, who has granted bioRxiv a license to display the preprint in perpetuity. It is made available under aCC-BY 4.0 International license.

135 threshold $=0.175$ (Fig. 2b) was due to the break-up of a large connected component (analogous plots

136 for communities with at least 3 plasmid members are shown in Fig. S1a-b).

138 The application of different MASH distance thresholds revealed different community structures within

139 the network. Fig. 2c shows the kernel density estimates (KDEs) of MASH distances stratified by 140 sampling compartment, with an overall range of [0, 0.602], highlighting that livestock plasmids 141 (median $=0.152$ ) were generally more similar to each other than WwTW plasmids (median=0.258) and 142 suggesting that plasmid diversity was higher in WwTW isolates. A distance threshold low enough to 143 reveal the livestock sub-network structure could destroy the structure of the WwTW sub-network, so 144 for this study, we selected a threshold $=0.05$, which revealed the structure of livestock plasmids at the 145 expense of some WwTW structure break-up. Note that this threshold is far lower than those used in 146 previous plasmid network analyses of global plasmid diversity [21-23]; our sample was smaller and restricted to a broad plasmid family so required more severe sparsification to reveal communities. At 148 this level, the network's largest connected component (LCC) had 201 nodes with 182 connected 149 components in total (Fig. 2d). It also had the highest number of communities (13) containing at least 10 150 plasmids (Fig. 2a), and coverage of over 50\% (Fig. 2b). There were 99 singleton plasmids, consistent 151 with high levels of diversity in the population. A visualisation of the network at this threshold with the 15213 communities coloured is presented in Fig. 3.

\section{Community metadata analysis}

155 To evaluate the relationship between the node metadata labels and the network, two entropic measures 156 were considered: homogeneity $(h)$ and completeness $(c)$ (both range from $0-1$; see Materials and 157 Methods). Homogeneity measures the distribution of labels given a community, with an ideal 158 community containing a single label: a high homogeneity means that plasmids with similar sequences tend to have similar metadata labels. Conversely, completeness measures the distribution of

160 communities given a label: a high completeness means that instances of a label tend to fall within a 161 single community. Importantly, both homogeneity and completeness are independent of community 
bioRxiv preprint doi: https://doi.org/10.1101/2020.07.24.215889; this version posted July 24,2020. The copyright holder for this preprint (which was not certified by peer review) is the author/funder, who has granted bioRxiv a license to display the preprint in perpetuity. It is made available under aCC-BY 4.0 International license.

162 size, the number of communities, and the number of metadata labels. This makes the approach robust

163 to uneven sampling strategies, such as the disproportionate number of $E$. coli isolates in our sample.

165 Each plasmid was assigned a set of metadata labels, consisting of a sampling compartment (livestock type [pig, cattle, sheep] or WwTW-association [influent, effluent, upstream, downstream]), a host genus (Citrobacter, Enterobacter, Escherichia or Klebsiella), and a time-point (1, 2 or 3). Homogeneity (Table 1) and completeness (Table 2) were averaged over 100 runs of the Louvain

169 algorithm. Despite the number of communities remaining consistent, some variation in the measures 170 arose from minor changes in community boundaries.

172 Homogeneity scores showed that sampling compartment shaped plasmid similarity. At the coarsest resolution there was high homogeneity considering livestock versus WwTW $(h=0.715$; Table 1$)$, meaning that plasmid communities were largely distinct between livestock and WwTW settings. This metadata partition is projected on the network in Fig. 4a. However, homogeneity was lower when comparing different livestock types (pig, cattle, sheep) $(h=0.591)$ and even more so when comparing different farms $(h=0.403)$, meaning that there was a loss of structure at these levels and plasmid communities were not well segregated by individual farm. Homogeneity was also low if plasmids were stratified by individual WwTWs $(h=0.467)$. However, homogeneity increased for influent/upstream versus effluent/downstream compartments $(h=0.550)$ indicating some differences in plasmids before and after WwTW treatment. Overall, plasmids from WwTWs were weakly structured

182 by wastewater catchment.

184 Completeness scores highlighted higher WwTW diversity compared to lower livestock diversity. For

185 the binary livestock or WwTW label plasmid communities scored a low completeness (Table 2; $c=0.199)$, which changed little when stratified over the individual WwTWs $(c=0.238)$, indicating a uniform distribution of WwTW labels over the plasmid communities and high diversity. Based on our

188 MASH distance KDEs (Fig. 2c), we would expect livestock plasmids to have higher completeness 189 scores than WwTW plasmids due to the lower levels of diversity; as anticipated, when stratifying the 
bioRxiv preprint doi: https://doi.org/10.1101/2020.07.24.215889; this version posted July 24,2020. The copyright holder for this preprint (which was not certified by peer review) is the author/funder, who has granted bioRxiv a license to display the preprint in perpetuity. It is made available under aCC-BY 4.0 International license.

190 livestock metadata, completeness scores increased $(c=0.332$ and $c=0.400)$. This indicated plasmids

191 from the same farm were more likely to be found in the same community.

192

193 Host genus also played an important factor in partitioning plasmid diversity. The homogeneity scores

194 were very high, implying a significant genetic partition by host (Table $1 ; h=0.888$ ). This metadata

195 partition is displayed in Fig. 4b. The lower completeness suggested a moderate level of diversity

196 across all Enterobacteriaceae plasmids (Table 2; $c=0.307$ ). There was a very weak time-point effect

197 found in the network (Tables 1,$2 ; h=0.050$ and $c=0.023$ ). Under a one-tailed permutation test, all

198 metadata label configurations except time-point had a zero $p$-value for homogeneity and completeness

199 (Table S2; see Materials and Methods), indicating that overall, there was a significant association

200 between niche (sampling compartment and host genus) and plasmid population structure.

201

202

Community pangenomes

203 To explore the genetic structure of the communities we considered the set of all represented genes

204 within a community, known as the pangenome (see Materials and Methods). Plasmids had a median

205 of 35 annotated genes (range $=4-112)$. Genes conferring AMR were found in $17 \%(122 / 726)$ of

206 plasmids; this included 33 plasmids carrying ESBLs (9 pig, 8 cattle and 16 WwTw), with 4 carrying

207 bla $a_{\mathrm{CTX}-\mathrm{M}-15}$ (all WwTW). IncF plasmids in isolates cultured from pigs were disproportionately

208 associated with AMR genes (45/109 [41\%] AMR plasmids).

209

210 Core genes with well-conserved synteny comprise the plasmid 'backbone' [18], which often controls

211 essential replication and mobility functions. Genes with accessory function, such as AMR genes, are

212 inserted into the backbone. For the 13 IncF plasmid communities identified in this study using the

2130.05 threshold above (see Fig. 3), we found a median of 13 core genes (range $=0-88$ ) (Table 3 ). Each

214 community possessed a unique combination of core genes, and pairs of communities shared a median

215 of 0 core genes between them (range $=0-21$ ) (Table S3). The communities had a median of 463

216 accessory genes (range $=151-790)$, sharing a median of 312 accessory genes (range=99-570) $($ Table

217 S4). Pairs of communities sharing a higher number of genes tended to have a higher sum of individual 
bioRxiv preprint doi: https://doi.org/10.1101/2020.07.24.215889; this version posted July 24,2020. The copyright holder for this preprint (which was not certified by peer review) is the author/funder, who has granted bioRxiv a license to display the preprint in perpetuity. It is made available under aCC-BY 4.0 International license.

218 genes $(r=0.820, t=12.505, p$-value $<2.2 \mathrm{e}-16)$, indicating overlap between larger pangenomes. Within a

219 plasmid community, a lower mean MASH value indicates greater overall sequence similarity; as

220 anticipated therefore, we found a lower mean MASH distance was associated with more core genes

$221(r=-0.615, t=-2.586, p$-value $=0.025)$ and a lower total number of genes in the pangenome $(r=0.654$,

$222 t=2.865, p$-value $=0.015)$.

223

224 For an example community of 30 IncF plasmids from isolates from sheep farms, we produced a

225 neighbour-joining phylogeny based on 64/384 core genes (Fig. 5). The tree accounts for homologous

226 recombination, with events detected in 11/30 leaf nodes and 21 internal nodes, consistent with a high

227 number of exchange events affecting this plasmid community. The median tract length was 156bp

228 (range=2bp-2249bp). Annotation of the phylogeny with the 316 accessory genes for this community

229 revealed that accessory gene presence aligned almost identically with the core gene phylogeny,

230 suggesting that the evolution of the plasmid backbone is highly linked to accessory function. All host

231 genera for this plasmid community were diverse E. coli, with 13 known STs present, consistent with

232 widespread horizontal transfer of the plasmids from this community. Within this community, no

233 plasmids carried AMR genes. Core genome phylogenies for other plasmid communities also showed a

234 strong link between accessory gene presence and backbone contents (Figs. S2-S12).

\section{Discussion}

237 We have analysed plasmid communities using distance-free genomic networks to explore diversity

238 within a large, natural population of IncF plasmids from four Enterobacteriaceae genera (Citrobacter,

239 Enterobacter, Escherichia and Klebsiella). These IncF plasmids contained a diversity of replicons

240 (plasmids contained 21 other replicons, forming 62 unique combinations) and we resolved plasmids

241 into communities ( 12 communities of $\geq 10$ plasmids). We found that $15 \%$ of IncF plasmids contained

242 at least one AMR gene, and 5\% carried an ESBL. This underlines that non-clinical plasmid

243 populations can also carry AMR genes, and that WwTW environment and livestock niches are part of

244 an AMR network for Enterobacteriacae [2, 10]. 
bioRxiv preprint doi: https://doi org/101101/2020 07 24.215889; this version posted July 24, 2020. The copyright holder for this preprint (which was not certified by peer review) is the author/funder, who has granted bioRxiv a license to display the preprint in perpetuity. It is made available under aCC-BY 4.0 International license.

246 Our network analysis revealed IncF plasmids were well partitioned by sampling compartment, with

247 distinct communities isolated to WwTWs or livestock; however, there were also clear instances of

248 sharing events between, for example, specific farm locations. There was also moderate partitioning by

249 specific livestock species: pig, cattle and sheep. Additionally, there was a difference in plasmids

250 before and after WwTW treatment. Sampling compartment also influenced diversity, with a higher

251 diversity in WwTW-associated plasmids than livestock plasmids. This is probably because both river

252 and wastewater catchments integrate a large number of human, livestock (farmed and wild) and

253 environmental sources. Further, they also experience higher rates of inflow and outflow than farm-

254 specific environments. The analysis also revealed a significant partition by host genera. Despite IncF

255 plasmids ranging over all Enterobacteriaceae genera, it suggested some genus-specific adaptations.

256 Notably, the extent of plasmid-host AT-richness relative to the host chromosome varied depending on

257 the genus. It remains to be seen how such observed differences relate to plasmid function. However,

258 this may be related to the livestock-WwTW partition, since our livestock plasmids were

259 predominantly hosted by E. coli. We did not detect an effect of sampling time-point. This is may be

260 because our time-points were too close and sample size too small to capture any significant evolution,

261 or it may indicate that time of year is not a strong factor in determining community structure. It would

262 be interesting to see how plasmids from clinical samples relate to those from our samples within the

263 network, especially if pre-WwTW plasmids are considered as a proxy for human gut microbiomes.

265 Pangenome analysis of the inferred plasmid communities revealed that core gene content was mostly

266 unique to communities. Further, they were strongly related to accessory function. Taken with the

267 above results, we propose that sampling compartment and host greatly influence the function of

268 plasmids. This includes AMR presence, with pigs, and hence Escherichia, carrying a disproportionate

269 burden in our sample. The pangenomes for communities varied greatly in the number of core genes,

270 with one community having zero. This may be because the threshold was not severe enough to

271 segregate this particular community into uniquely similar groups. It also may result from how

272 Panaroo (see Materials and Methods) corrects annotation errors, splitting gene clusters too readily.

273 Generally, more genetically similar communities possessed a greater number of core genes and 
bioRxiv preprint doi: https://doi.org/10.1101/2020.07.24.215889; this version posted July 24,2020. The copyright holder for this preprint (which was not certified by peer review) is the author/funder, who has granted bioRxiv a license to display the preprint in perpetuity. It is made available under aCC-BY 4.0 International license.

274 smaller pangenome. Our results for IncF plasmid communities are in line with a recent study of the

275 wider prokaryotic plasmidome which concluded that clusters of plasmids contain common genomic

276 backbones [23].

278 Our study has several limitations. One important limitation, which applies more widely to network approaches which cluster or partition diversity, is that thresholding of the network is highly subjective and dataset dependent. Trade-offs are required to reveal the intermediate structures of the network whilst maintaining good community detection performance. We determined a threshold by considering MASH distance distributions and component evolution alongside Louvain output diagnostics. When diversity varies greatly between sampling compartments, a single threshold is unlikely to be globally optimal. In these cases, it is probably best to focus on sub-populations of interest. Despite only considering several hundred nodes here, our methodology is scalable to far larger studies. Originally, the Louvain algorithm had runtime complexity $O(e)$, where $e$ is the number of edges in the network. This has since been improved to $O(v \log k)$, where $v$ is the number of nodes and $k$ is the average node degree [28]. Further, recent efforts have parallelised the Louvain algorithm to networks with billions of edges, though this approach was not necessary here [29]. Finally, our dataset is limited to the four Enterobacteriaceae genera under study and conclusions may not reflect the wider diversity of IncF plasmids beyond these genera.

In conclusion, our study adds to the growing literature on distance-free networks to characterise and

294 partition plasmid diversity, introducing a scalable framework to quantify the relationship between 295 network structure and plasmid metadata by identifying network communities. Overall, our approach 296 represented a high-resolution strategy for summarising similarities and differences within plasmid 297 populations, leveraging the advantages of having complete plasmid sequences and analysing these in 298 the context of associated metadata. For IncF plasmids we were able to show the distinct, local effects of sampling compartment on plasmid structure and population, but also identify evidence for sharing

300 of plasmids between bacterial lineages, farms and WwTW-associated contexts, with relevance for the

301 "One Health"-associated study of mobile genetic elements and AMR genes. As long-read sequencing 
bioRxiv preprint doi: https://doi.org/10.1101/2020.07.24.215889; this version posted July 24, 2020. The copyright holder for this preprint (which was not certified by peer review) is the author/funder, who has granted bioRxiv a license to display the preprint in perpetuity. It is made available under aCC-BY 4.0 International license.

302 costs fall, and increasingly large numbers of plasmids can be characterised, future work applying this

303 method will contribute to better understanding plasmid populations, estimating transfer rates of

304 important AMR genes and MGEs between potential reservoirs, and identifying hotspots of

305 selection/transfer that might be amenable to intervention. 
bioRxiv preprint doi: https://doi.org/10.1101/2020.07.24.215889; this version posted July 24, 2020. The copyright holder for this preprint (which was not certified by peer review) is the author/funder, who has granted bioRxiv a license to display the preprint in perpetuity. It is made available under aCC-BY 4.0 International license.
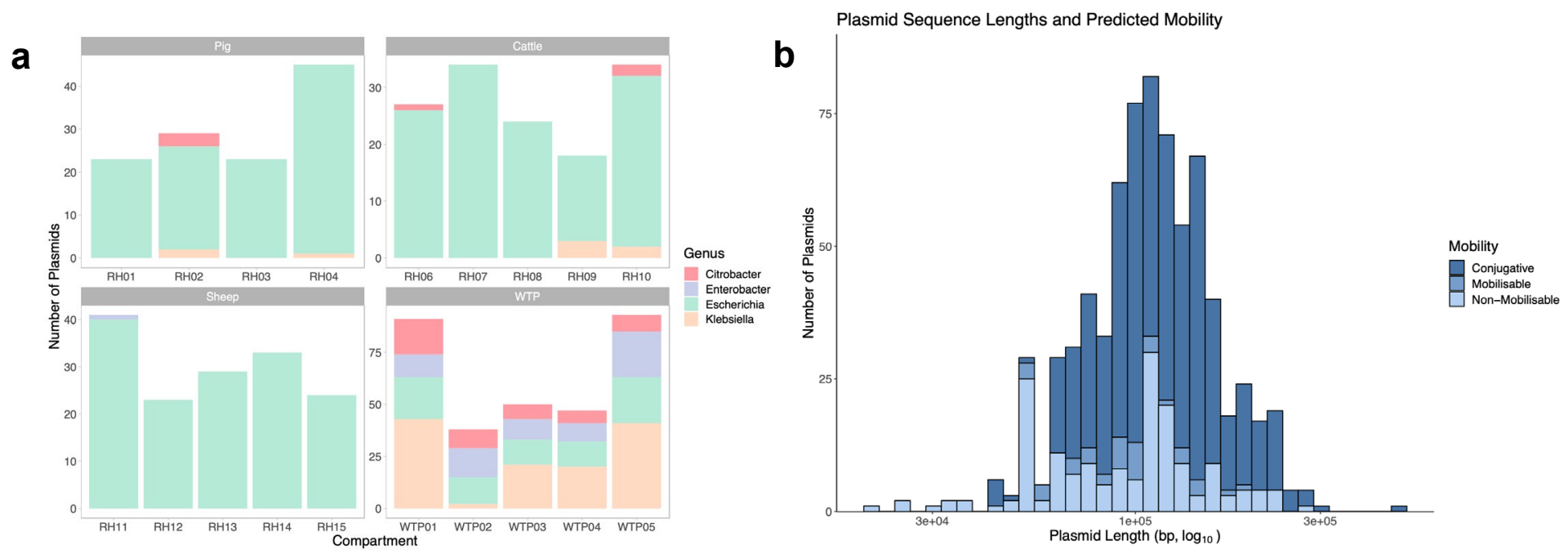

C

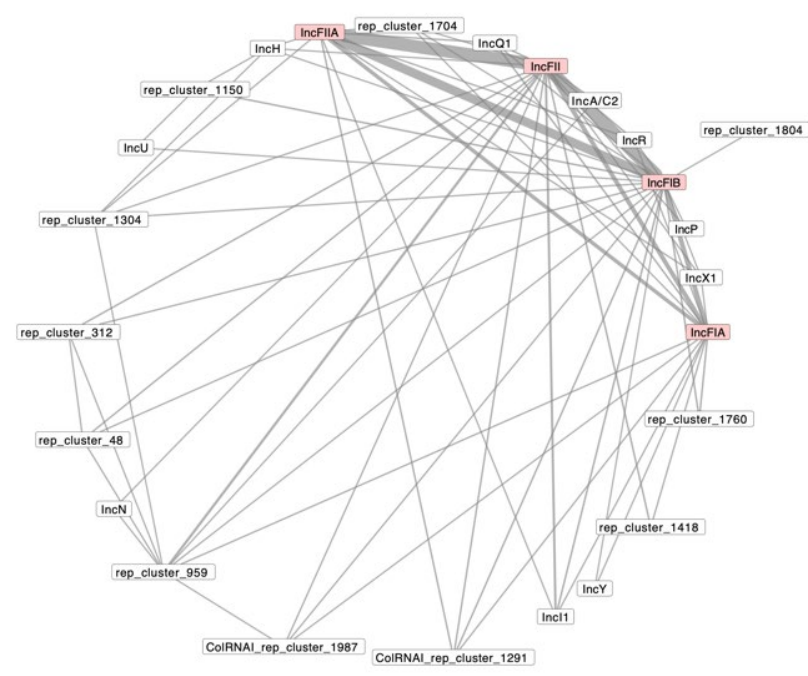

d

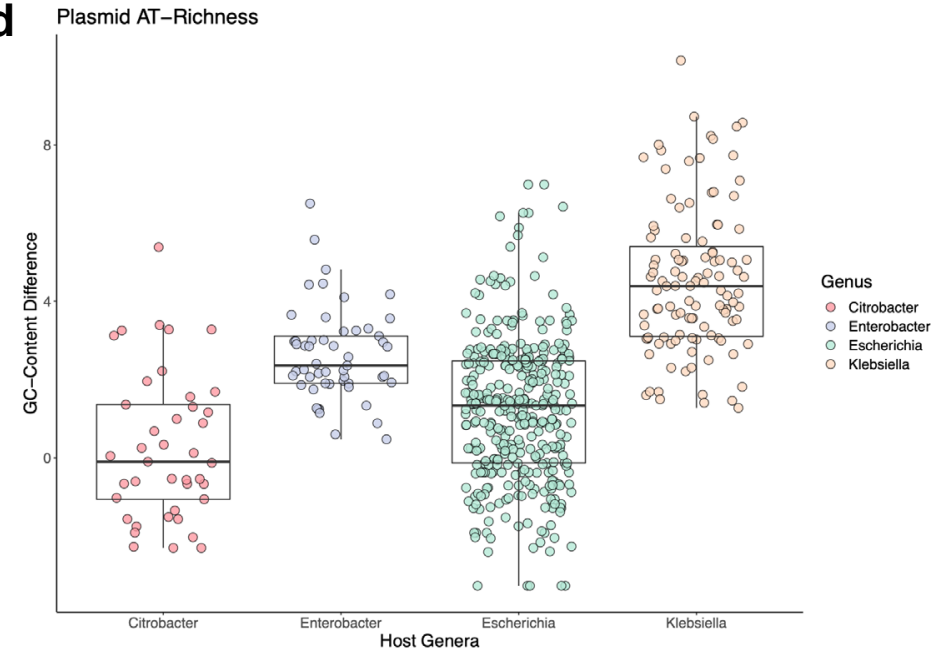

Figure 1. Overview of plasmid population. (a) Plasmid host genera distribution by compartment. (b) Distribution of plasmid sequence lengths with predicted mobilities. (c) Graph representing the association between replicon alleles. IncF nodes are coloured pink. Line weight is proportional to frequency of association in the sample. (d) Plasmid GC-content subtracted from host chromosome GC-content. A value greater than zero indicates the plasmid is AT-richer than the host. Only plasmids with circularised host chromosomes were used (565/726). 
bioRxiv preprint doi: https://doi.org/10.1101/2020 07.24.215889; this version posted July 24, 2020. The copyright holder for this preprint (which was not certified by peer review) is the author/funder, who has granted bioRxiv a license to display the preprint in perpetuity. It is made available under aCC-BY 4.0 International license.

a

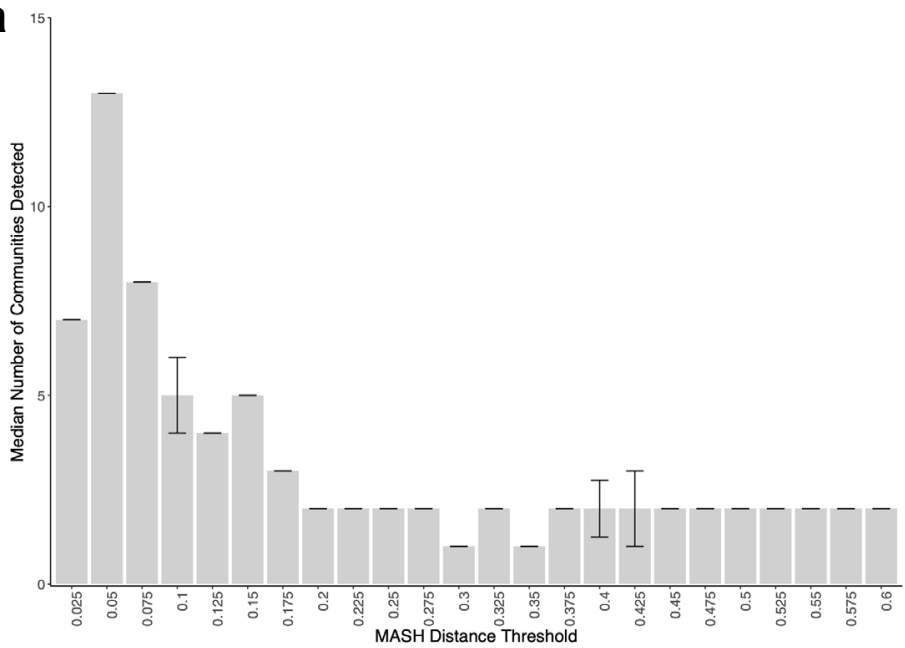

C

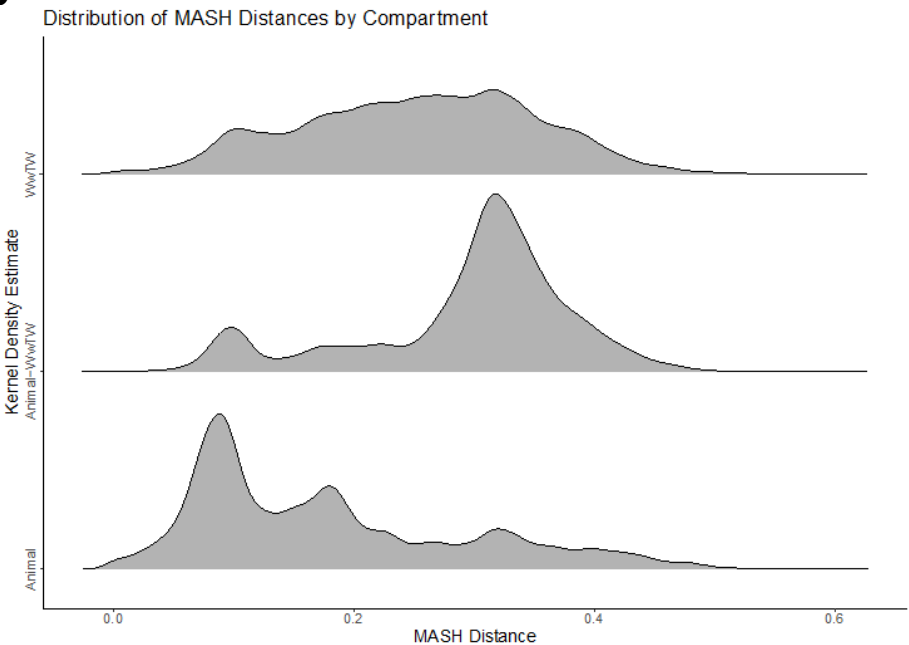

b

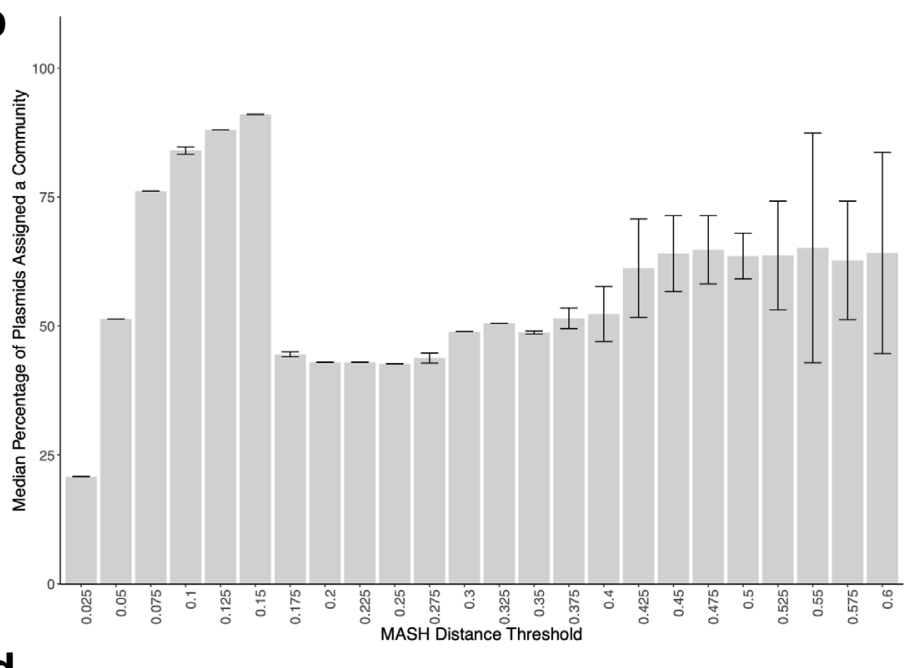

d

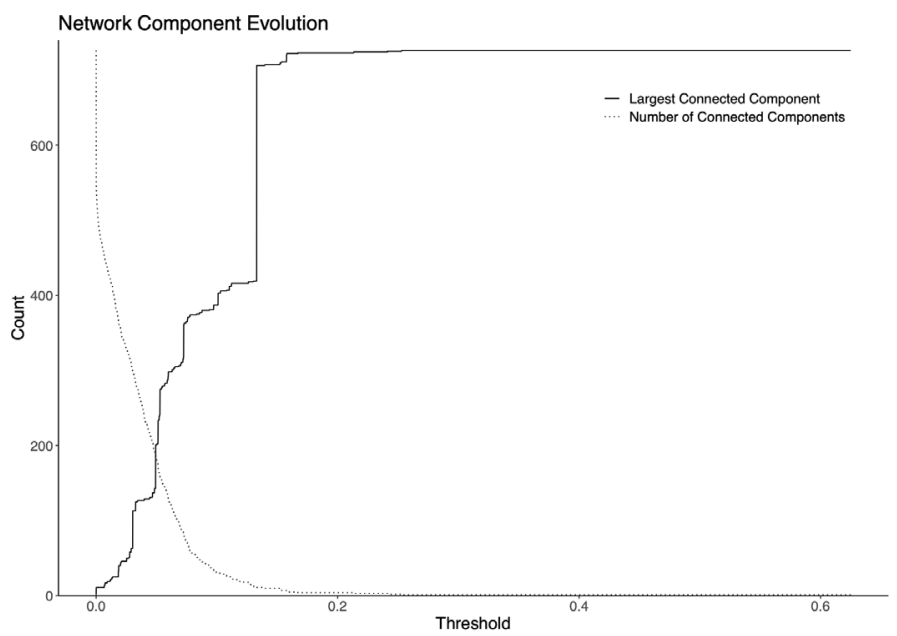

Figure 2. Thresholding the plasmid network. (a) Number of communities (at least 10 nodes) detected over a varying MASH threshold. Median and IQR bars shown. (b) Community coverage of the network over a varying MASH threshold. Median and IQR bars shown. (c) Gaussian kernel density estimates of MASH distances stratified by compartment. Bandwidth calculated by Silverman's 'rule of thumb'. (d) Evolution of the largest connected component and number of components over a varying MASH threshold. 
bioRxiv preprint doi: https://doi.org/10.1101/2020.07.24.215889; this version posted July 24, 2020. The copyright holder for this preprint (which was not certified by peer review) is the author/funder, who has granted bioRxiv a license to display the preprint in perpetuity. It is made available under aCC-BY 4.0 International license.
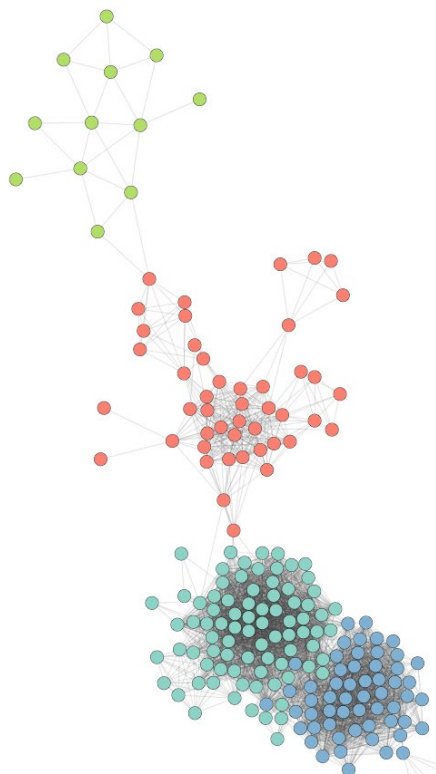

10
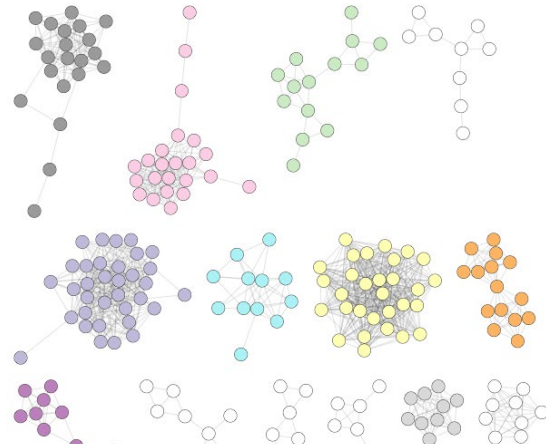
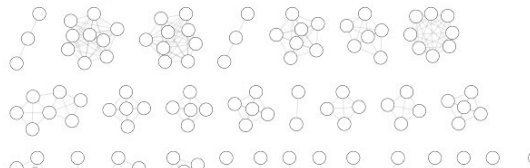

0000000000000000

000000000000000

$\begin{array}{lllllllllllllll}0 & 0 & 0 & 0 & 0 & 0 & 0 & 0 & 0 & 0 & 0 & 0 & 0 & 0 & 0 \\ 00 & 0 & 0 & 0 & 0 & 0 & 0 & 0 & 0 & 0 & 0 & 0\end{array}$

0000000000000000000000000000000

000000000000000000000000000000000000 000000000000000000000000000000000000

0000000000000

Figure 3. Plasmid network communities. The plasmid network at threshold $=0.05$. Each community with at least 10 members has unique colour. Unassigned plasmids and those in smaller communities are left white. 
bioRxiv preprint doi: https://doi.org/10.1101/2020.07.24.215889; this version posted July 24, 2020. The copyright holder for this preprin (which was not certified by peer review) is the author/funder, who has granted bioRxiv a license to display the preprint in perpetuity. It is made available under aCC-BY 4.0 International license.

a

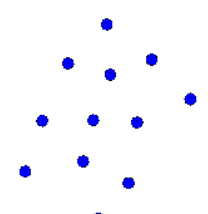

-

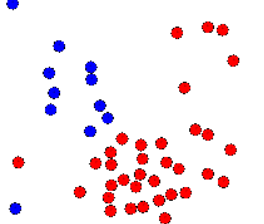

$$
:
$$
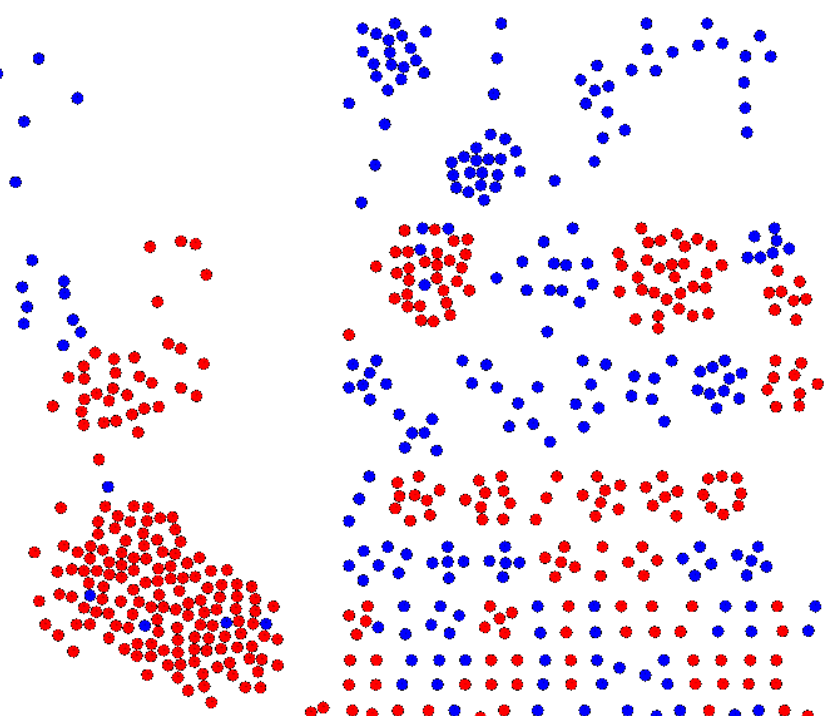

$\therefore \because \because 8: \because \because 8 \%$

$\because \because \bullet \bullet \bullet \bullet: \because \cdots \bullet \bullet \bullet$

$\because: \because: \because::: \because: \because: \because::$

$\therefore: \because: \because \because \cdots: \cdots: \cdots$

$\because:: \because: \because: \because:: \because: \because \because:$

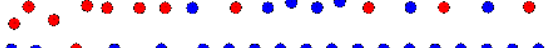

$\therefore \because \because \because \therefore \because \because \because \because \because \because \bullet \bullet \bullet$

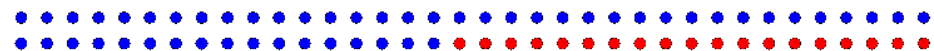

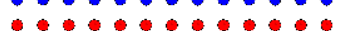

b

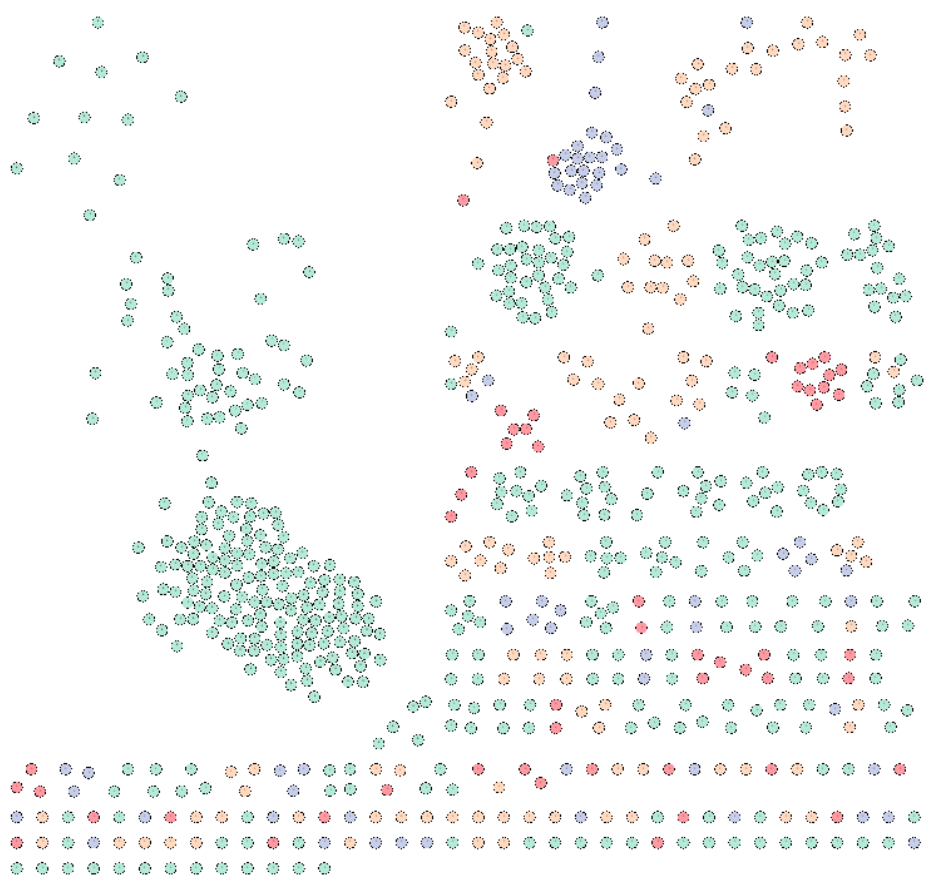

Citrobacter

Enterobacter

Escherichia

Klebsiella

Livestock
WwTW

Figure 4. Plasmid network coloured by metadata. All nodes are coloured, not just those in our detected 13 communities of at least 10 members. (a) Partition by livestock or WwTW sampling compartment. (b) Partition by plasmid host genera. 
bioRxiv preprint doi: https://doi.org/10.1101/2020.07.24.215889; this version posted July 24, 2020. The copyright holder for this preprint (which was not certified by peer review) is the author/funder, who has granted bioRxiv a license to display the preprint in perpetuity. It is made available under aCC-BY 4.0 International license.

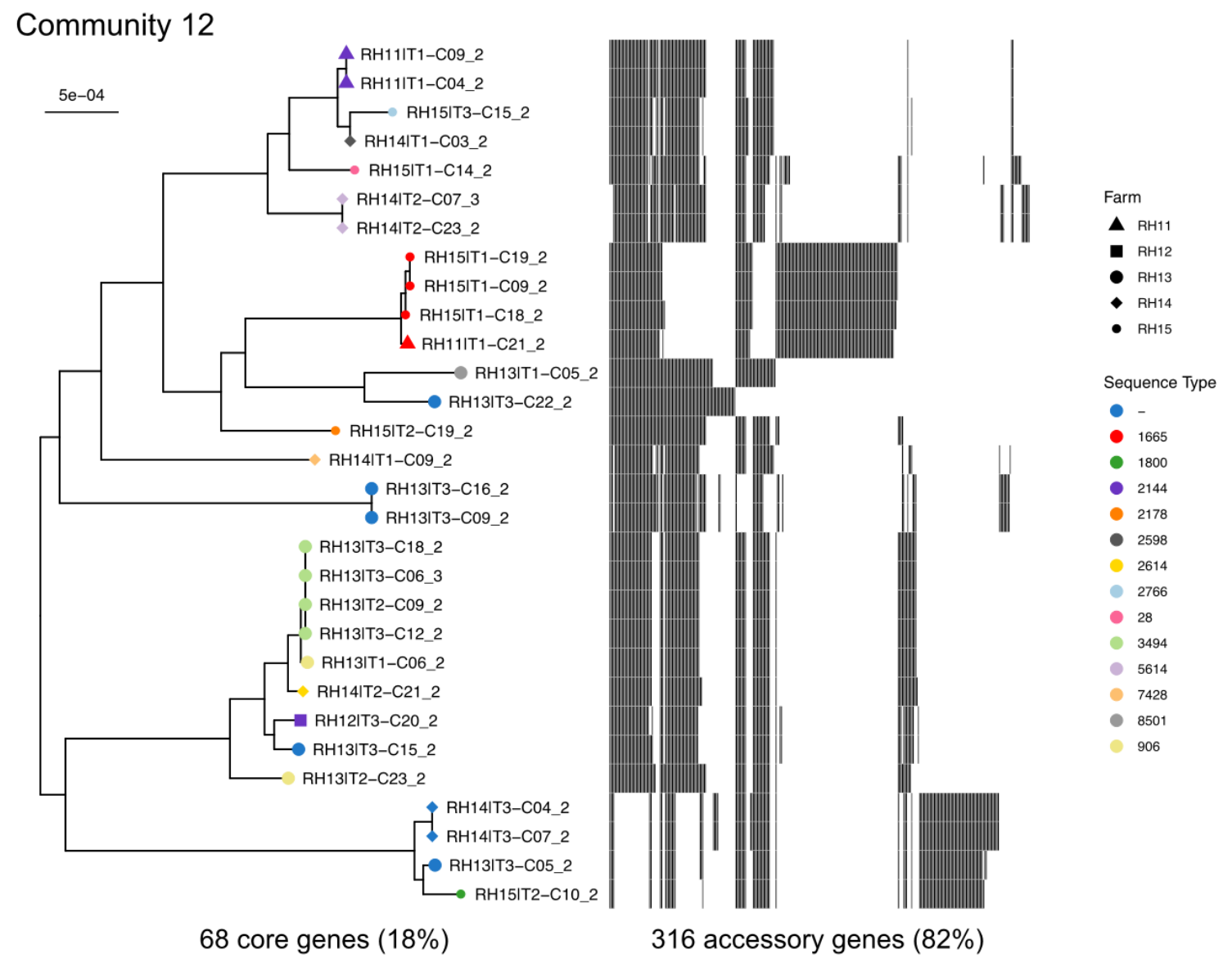

Figure 5. Community core gene phylogeny. A neighbour-joining tree based on alignments of the 68 core genes. A heatmap of the 316 accessory genes is also shown. Node colour represents host sequence type and node shape represents farm. Unknown STs are labelled by '-'. Branch lengths have been corrected for homologous recombination. 
bioRxiv preprint doi: https://doi.org/10.1101/2020.07.24 215889; this version posted July 24,2020 . The copyright holder for this preprint (which was not certified by peer review) is the author/funder, who has granted bioRxiv a license to display the preprint in perpetuity. It is made available under aCC-BY 4.0 International license.

Table 1. Community metadata homogeneity.

\begin{tabular}{|l|l|l|l|l|l|l|l|}
\hline & \multicolumn{6}{|c|}{ Mean \pm sd Homogeneity } \\
\hline $\begin{array}{l}\text { Median } \pm \text { IQR } \\
\text { Communities } \\
\text { with at least 10 } \\
\text { Plasmids }\end{array}$ & $\begin{array}{l}\text { Livestock, } \\
\text { WwTW }\end{array}$ & $\begin{array}{l}\text { Pig, } \\
\text { Cattle, } \\
\text { Sheep, } \\
\text { WwTW }\end{array}$ & $\begin{array}{l}14 \\
\text { Livestock } \\
\text { Farms, } \\
\text { WwTW }\end{array}$ & $\begin{array}{l}\text { Livestock, } \\
5 \text { WwTWs }\end{array}$ & $\begin{array}{l}\text { Livestock, } \\
\text { Upstream/ } \\
\text { Influent, } \\
\text { Downstream/ } \\
\text { Effluent }\end{array}$ & $\begin{array}{l}\text { Host } \\
\text { Genera }\end{array}$ & $\begin{array}{l}\text { Time- } \\
\text { point }\end{array}$ \\
\hline $13 \pm 0$ & $\begin{array}{l}0.715 \pm \\
0.002\end{array}$ & $\begin{array}{l}0.591 \pm \\
0.008\end{array}$ & $\begin{array}{l}0.403 \pm \\
0.005\end{array}$ & $\begin{array}{l}0.467 \pm \\
0.012\end{array}$ & $0.550 \pm 0.009$ & $\begin{array}{l}0.888 \pm \\
0.000\end{array}$ & $\begin{array}{l}0.050 \pm \\
0.001\end{array}$ \\
\hline
\end{tabular}

Table 1. Community metadata homogeneity. Homogeneity score averages over 100 runs of the Louvain algorithm for all 13 communities.

Table 2. Community metadata completeness.

\begin{tabular}{|l|l|l|l|l|l|l|l|}
\hline & \multicolumn{6}{|c|}{ Mean \pm sd Completeness } \\
\hline $\begin{array}{l}\text { Median } \pm \text { IQR } \\
\text { Communities } \\
\text { with at least 10 } \\
\text { Plasmids }\end{array}$ & Livestock, & $\begin{array}{l}\text { Pig, } \\
\text { WwTW } \\
\text { Cattle, } \\
\text { Sheep, } \\
\text { WwTW }\end{array}$ & $\begin{array}{l}14 \\
\text { Livestock } \\
\text { Farms, } \\
\text { WwTW }\end{array}$ & $\begin{array}{l}\text { Livestock, } \\
5 \text { WwTWs }\end{array}$ & $\begin{array}{l}\text { Livestock, } \\
\text { Upstream/ } \\
\text { Influent, } \\
\text { Downstream/ } \\
\text { Effluent }\end{array}$ & $\begin{array}{l}\text { Host } \\
\text { Genera }\end{array}$ & $\begin{array}{l}\text { Time- } \\
\text { point }\end{array}$ \\
\hline $13 \pm 0$ & $\begin{array}{llllll}0.199 \pm \\
0.002\end{array}$ & $\begin{array}{l}0.332 \pm \\
0.001\end{array}$ & $\begin{array}{l}0.400 \pm \\
0.001\end{array}$ & $\begin{array}{l}0.238 \pm \\
0.002\end{array}$ & $0.211 \pm 0.002$ & $\begin{array}{l}0.307 \pm \\
0.002\end{array}$ & $\begin{array}{l}0.023 \pm \\
0.000\end{array}$ \\
\hline
\end{tabular}

Table 2. Community metadata completeness. Completeness score averages over 100 runs of the Louvain algorithm for all 13 communities. 
bioRxiv preprint doi: https://doi.org/10.1101/2020.07.24.215889; this version posted July 24, 2020. The copyright holder for this preprint (which was not certified by peer review) is the author/funder, who has granted bioRxiv a license to display the preprint in perpetuity. It is made available under aCC-BY 4.0 International license.

Table 3. Community pangenome results.

\begin{tabular}{|l|l|l|l|l|l|l|l|l|}
\hline Community & Nodes & Edges & $\begin{array}{l}\text { MASH } \\
\text { mean }\end{array}$ & $\begin{array}{l}\text { Core } \\
\text { Genes }\end{array}$ & $\begin{array}{l}\text { Soft Core } \\
\text { Genes }\end{array}$ & $\begin{array}{l}\text { Shell } \\
\text { Genes }\end{array}$ & $\begin{array}{l}\text { Cloud } \\
\text { Genes }\end{array}$ & $\begin{array}{l}\text { Total } \\
\text { Genes }\end{array}$ \\
\hline 1 & 61 & 1252 & 0.0284 & 3 & 6 & 172 & 263 & 444 \\
\hline 2 & 82 & 1817 & 0.0314 & 4 & 18 & 138 & 364 & 524 \\
\hline 3 & 46 & 325 & 0.0355 & 35 & 8 & 86 & 369 & 498 \\
\hline 4 & 12 & 21 & 0.0382 & 2 & 0 & 290 & 129 & 421 \\
\hline 5 & 14 & 23 & 0.0383 & 2 & 0 & 225 & 260 & 487 \\
\hline 6 & 21 & 111 & 0.0366 & 13 & 6 & 354 & 430 & 803 \\
\hline 7 & 34 & 263 & 0.0344 & 2 & 1 & 278 & 359 & 640 \\
\hline 8 & 23 & 135 & 0.0222 & 27 & 1 & 142 & 362 & 532 \\
\hline 9 & 12 & 34 & 0.0344 & 18 & 0 & 364 & 324 & 706 \\
\hline 10 & 13 & 37 & 0.0233 & 0 & 0 & 309 & 38 & 347 \\
\hline 11 & 15 & 55 & 0.0194 & 62 & 0 & 116 & 35 & 213 \\
\hline 12 & 30 & 391 & 0.0242 & 68 & 3 & 126 & 187 & 384 \\
\hline 13 & 12 & 45 & 0.0223 & 88 & 0 & 195 & 48 & 331 \\
\hline
\end{tabular}

Table 3. Community pangenomes. Characteristics of each of the 13 communities, including number of nodes, edges and MASH mean (mean weight of all edges), and gene counts at each level of the pangenome: core genes, soft core genes, shell genes and cloud genes are those found in $[100,99],(99,95],(95,15]$, and $(15,0]$ percent of plasmids respectively. 


\section{Materials and Methods}

315 Plasmids and corresponding host isolates were sampled and sequenced on behalf of the REHAB

316 project in 2017, which aimed to characterise the non-clinical, non-human Enterobacteriaceae

317 microbiome in south-central England, with a focus on better understanding antimicrobial resistance

318 (AMR) spread. Specifically, livestock (pig farms, cattle farms and sheep farms) and wastewater

319 treatment work environments (WwTWs; influent, effluent, upstream and downstream waterways)

320 were sampled. To account for seasonal variation, sampling occurred at three discrete time-points

321 (TPs): January-April 2017 (TP1), June-July 2017 (TP2), October-November 2017 (TP3). All the

322 plasmids presented have at least one IncF replicon (classified by with MOB-typer, see below). In

323 total, we present $n=726$ plasmids originated from $n=558$ isolates. This comprises a subset of the entire

324 REHAB dataset, which overall contains $n=2,293$ circularised plasmids recovered from $n=828$ isolates.

325 This dataset is described in more detail [17].

327 Livestock. Four pig farms (RH01-04), five cattle (RH06-10) and five sheep farms (RH11-15) were

328 selected for sampling over all three TPs. All participating farmers provided written consent for

329 participation. Specific details on farm recruitment and sampling procedure can be found in [17] and

330 Anjum et al. (paper in preparation).

332 Wastewater treatment works (WwTWs) environment. Five WwTWs (WTP01-05) were selected

333 based on a number of criteria, including; geographic location within the region, wastewater treatment

334 configuration, wastewater population equivalent (PE) served, consented flow, and the accessibility of

335 the effluent receiving river for sampling both upstream and downstream. The chosen WwTWs and

336 their details are shown in Table S5. Sampling took place over all three TPs. Specific details are

337 provided in [17].

339 DNA sequencing. The isolates were selected for sequencing to represent diversity within the four

340 major genera (Citrobacter, Enterobacter, Escherichia and Klebsiella) in each niche, including the use 
bioRxiv preprint doi: https://doi.org/10.1101/2020.07.24.215889; this version posted July 24,2020. The copyright holder for this preprint (which was not certified by peer review) is the author/funder, who has granted bioRxiv a license to display the preprint in perpetuity. It is made available under aCC-BY 4.0 International license.

341 of third-generation cephalosporin resistance to identify a subset of multi-drug resistant isolates within

342 each genus. Sequencing involved either PacBio SMRT $(n=293)$ or Oxford Nanopore Technologies

343 (ONT) $(n=268)$ methodologies. Specific details are provided in [17].

344

345 Genome assembly, assignment and typing. We used the hybrid assembly and sequencing methods described in our pilot study [30] to produce high-quality Enterobacteriaceae genomes from short and long reads. We assigned species and sequence type (ST) from assembled genomes using mlst (version 2.16.43) [31]. Further details on validation are provided in [17].

Plasmid assembly. We used the hybrid assembly and sequencing methods described in a pilot study

351 [30] to produce high-quality Enterobacteriaceae genomes from short and long reads. In short, we used Unicycler (version 0.4.7) [32] with 'normal' mode, --min_component_size 500, -min_dead_end_size 500, and otherwise default parameters. From these, we selected $n=726$ plasmids which contained an IncF replicon after classification with MOB-typer (see below). We searched all plasmids against PLSDB (version 2020-03-04) [33] which contains 20,668 complete published plasmids, using mash screen [34] and keeping the top hit. All plasmids had a match.

Mobility typing. We used MOB-typer from MOB-suite (version 2.0.0) [35]. We clustered plasmids using MOB-cluster and assigned replicon types with MOB-typer, both part of the MOB-suite. MOBcluster uses single linkage clustering with a cutoff of a mash distance of 0.05 (corresponding to $95 \%$ ANI). A recent large-scale study [12] showed MOB-typer to have a higher correct classification rate than the widely used PlasmidFinder [36].

364 Plasmid distance estimation. Distances between the complete plasmid sequences was calculated using MASH (version 2.2) [27]. MASH reduces sequences to a fixed-length MinHash sketch, which is used to estimate the Jaccard index. This measures extent of $k$-mer sharing between plasmids. The representative sketch is far shorter than the original sequence, making distance calculations efficient over large datasets. A $k$-mer length of 13 and a sketch size of 5000 was used. All other settings were 
bioRxiv preprint doi: https://doi.org/10.1101/2020.07.24.215889; this version posted July 24,2020. The copyright holder for this preprint (which was not certified by peer review) is the author/funder, who has granted bioRxiv a license to display the preprint in perpetuity. It is made available under aCC-BY 4.0 International license.

369 default. Using MASH considerably reduces distance computation time from exact $k$-mer profile

370 methods, whilst maintaining good performance.

372 Louvain community detection. The Louvain algorithm detects communities by optimising the modularity by iterative expectation-maximisation (EM) [19]. This aims to maximise the density of edges within communities against edges between communities. The algorithm was implemented using the python-louvain (version 0.14) Python module.

Community metadata analysis. Homogeneity $(h)$ and completeness $(c)$ are dual conditional entropybased measures [37]. They are independent of clustering algorithm, dataset size, number of labeltypes, number of communities and community sizes. This means they are appropriate for uneven metadata distributions. A community partition satisfies homogeneity $(h=1)$ if all members have the same metadata label-type. Suppose we have network with $N$ nodes, partitioned by a set of metadata labels, $M=\left\{m_{i} \mid i=1, \ldots, n\right\}$, and a set of communities, $C=\left\{c_{j} \mid j=1, \ldots, m\right\}$. Let $A=\left\{a_{i j}\right\}$ represent the $i j^{\text {th }}$ entry in the contingency table of partitions. Hence, $a_{i j}$ counts the number of nodes with label $m_{i}$ in community $c_{j}$. We then say

$$
\mathrm{h}= \begin{cases}1 & \text { if } H(M, C)=0 \\ 1-\frac{H(M \mid C)}{H(M)} & \text { else }\end{cases}
$$

where

$$
H(M \mid C)=-\sum_{c=1}^{|C|} \sum_{m=1}^{|M|} \frac{a_{m c}}{N} \log \frac{a_{m c}}{\sum_{c=1}^{|M|} a_{m c}}
$$

and

$$
H(M)=-\sum_{m=1}^{|M|} \frac{\sum_{c=1}^{|C|} a_{m c}}{n} \log \frac{\sum_{c=1}^{|C|} a_{m c}}{n}
$$

390 are the conditional entropy of the metadata given the communities and the entropy of the

391 communities, respectively $H(M \mid C)=0$ when the community partition coincides with the metadata 
393 instances of a metadata label-type are assigned the same community. Completeness is defined dually

394 by

395

396

397

398

399

400

401

402

403

404 Plasmid annotation and pangenome analysis. Plasmids were annotated using Prokka (version

405

406

407

408

409

410

411

412

413 Community phylogeny. Alignment of core genes used Clustal Omega (version 1.2.4) [43], and

414 ClonalFrameML (version 1.2) [44] was used to adjust for homologous recombination. We used ggtree

415 (version 3.11) [45] to visualise the phylogeny.

416

Permutation test. We first calculated a Louvain partition for the network and selected all nodes in communities with at least 10 members. Homogeneity and completeness score medians were used from Table 1 and Table 2. The partition labels were then randomly permuted 1,000 times. For each permutation, the homogeneity and completeness scores were calculated. These were then used to calculate a right-tailed $p$-value. The results are shown in Table S2.

1.14.6) [39]. Pangenome analysis used Panaroo (version 1.2.2) [40]. Core genes, soft core genes, shell genes and cloud genes are those found in $[100,99],(99,95],(95,15]$, and $(15,0]$ percent of sequences respectively. Within the pangenome, core genes are typically defined as those shared by $\geq 99 \%$ of constituent plasmids. However, since no plasmid community in this study had $>100$ members, core genes were strictly shared by $100 \%$. AMR annotations used Abricate (version 0.9.8) [41] with with the NCBI AMRFinder Plus database [42] with a threshold of $90 \%$ sequence identity and $90 \%$ coverage.

$$
\text { (version } 3.11)[45] \text { to visualise the phylogeny. }
$$


bioRxiv preprint doi: https://doi org/10.1101/2020.07.24.215889; this version posted July 24,2020. The copyright holder for this preprint (which was not certified by peer review) is the author/funder, who has granted bioRxiv a license to display the preprint in perpetuity. It is made available under aCC-BY 4.0 International license.

417 Data visualization. All figures were made in using the R package ggplot2 (version 3.3.0) [46], except

418 for the network figures (1c, 3 and 4a-b), which were made using Cytoscape (version 3.8.0) [47].

419 Cytoscape was also used to calculate some network descriptive statistics.

420

421 Code and data availability. Plasmid sequence data, metadata (Table S6) and MASH edge list (Table

422 S7) output are available in a figshare collection (https://doi.org/10.6084/m9.figshare.c.5066684.v1).

423 Further details on computing methods can be found in the GitHub repository for the paper

424 (https://github.com/wtmatlock/plasmid-network-analysis). This includes scripts for calculating the

425 LCC and NCCs, Louvain performance diagnostics, and running the permutation test. Other data can

426 be found in [17].

427

428 Acknowledgements. The REHAB consortium is represented by the following: AbuOun M, Anjum

MF, Bailey MJ, Brett H, Bowes M, Chau KK, Crook DW, de Maio N, Duggett N, Wilson DJ, Gilson

430

D, Gweon HS, Hubbard A, Hoosdally SJ, Matlock W, Kavanagh J, Jones H, Peto TEA, Read DS,

431 Sebra R, Shaw LP, Sheppard AE, Smith R, Stubberfield E, Stoesser N, Swann J, Walker AS,

432 Woodford N. Also, thanks to Fowler P for his comments on the draft.

433

434 Author contributions. Author contributions under the CRediT system were as follows:

435 Conceptualisation: WM, NS, MA, DS, MJB, DWC, LPS, ASW

436 Methodology: WM, LPS

437 Software: WM

438 Validation: WM, KKC, LB, HP, LPS

439 Formal analysis: WM

440 Investigation: KKC, MA, ES, JK, HP, LB, RS, DSR, HSG, NS, RS

441 Resources: MA, MFA, HSG, DSR, RS, JS, NS, TEAP, MJB, ASW, RS

442 Data curation: WM, LPS, DSR, MA, NS, ES, DG

443 Writing - original draft: WM

444 Writing - review and editing: All authors 
bioRxiv preprint doi: https://doi.org/10.1101/2020.07.24.215889; this version posted July 24,2020. The copyright holder for this preprint (which was not certified by peer review) is the author/funder, who has granted bioRxiv a license to display the preprint in perpetuity. It is made available under aCC-BY 4.0 International license.

445 Visualisation: WM

446 Supervision: LPS, NS, ASW, DWC

447 Project administration: NS, DSR, SH, MFA

448 Funding acquisition: NS, DWC, MJB, DSR, MFA, ASW, TEAP

449

450 Competing interest declarations. The authors declare no competing interests.

451

452 Funding. This work was funded by the Antimicrobial Resistance Cross-council Initiative supported

453 by the seven research councils [grant NE/N019989/1]. Crook, George, Peto, Sheppard, Stoesser, and

454 Walker are supported by the National Institute for Health Research Health Protection Research Unit

455 (NIHR HPRU) in Healthcare Associated Infections and Antimicrobial Resistance at the University of

456 Oxford in partnership with Public Health England (PHE) [grant HPRU-2012-10041 and

457 NIHR200915]. Walker, Crook, and Peto are also supported by the NIHR Oxford Biomedical

458 Research Centre. Walker is an NIHR Senior Investigator. The computational aspects of this research

459 were funded from the NIHR Oxford BRC with additional support from a Wellcome Trust Core

460 Award Grant [grant 203141/Z/16/Z]. The views expressed are those of the authors and not necessarily

461 those of the NHS, the NIHR, the Department of Health or Public Health England. Matlock is

462 supported by a scholarship from the Medical Research Foundation National PhD Training Programme

463 in Antimicrobial Resistance Research (MRF-145-0004-TPG-AVISO).

464 


\section{References}

466 1. Thanner, S., D. Drissner, and F. Walsh, Antimicrobial resistance in agriculture. MBio, 467 2016.7(2).

$468 \quad 2 . \quad$ Wyres, K.L. and K.E. Holt, Klebsiella pneumoniae as a key trafficker of drug 469 resistance genes from environmental to clinically important bacteria. Current opinion in 470 microbiology, 2018. 45: p. 131-139.

$471 \quad 3 . \quad$ Collis, R.M., et al., Extended-Spectrum Beta-Lactamase-Producing

472 Enterobacteriaceae in Dairy Farm Environments: A New Zealand Perspective. Foodborne 473 pathogens and disease, 2019. 16(1): p. 5-22.

474 4. Velasova, M., et al., Detection of extended - spectrum $\beta$ - lactam, AmpC and 475 carbapenem resistance in Enterobacteriaceae in beef cattle in Great Britain in 2015. Journal 476 of applied microbiology, 2019. 126(4): p. 1081-1095.

477 5. AbuOun, M., et al., Characterizing Antimicrobial Resistant Escherichia coli and 478 Associated Risk Factors in a Cross-Sectional Study of Pig Farms in Great Britain. Frontiers 479 in Microbiology, 2020. 11.

480 6. Bartley, P.S., et al., Antibiotic resistance in Enterobacteriaceae from surface waters in 481 urban Brazil highlights the risks of poor sanitation. The American journal of tropical 482 medicine and hygiene, 2019. 100(6): p. 1369-1377.

483 7. Decano, A.G. and T. Downing, An Escherichia coli ST131 pangenome atlas reveals 484 population structure and evolution across 4,071 isolates. Scientific reports, 2019. 9(1): p. 148513.

486 8. Passarelli - Araujo, H., et al., Genomic analysis unveils important aspects of

487 population structure, virulence, and antimicrobial resistance in Klebsiella aerogenes. The 488 FEBS journal, 2019. 286(19): p. 3797-3810. 
489 9. Nakamura, K., et al., Differential dynamics and impacts of prophages and plasmids on

490 the pangenome and virulence factor repertoires of Shiga toxin-producing Escherichia coli

491 O145: H28. Microbial Genomics, 2020: p. mgen000323.

492 10. Woolhouse, M., et al., Antimicrobial resistance in humans, livestock and the wider

493 environment. Philosophical Transactions of the Royal Society B: Biological Sciences, 2015.

$494 \quad 370(1670):$ p. 20140083.

495 11. Allcock, S., et al., Antimicrobial resistance in human populations: challenges and

496 opportunities. Global health, epidemiology and genomics, 2017. 2.

497 12. Douarre, P.-E., et al., Analysis of COMPASS, a new comprehensive plasmid database

498 revealed prevalence of multireplicon and extensive diversity of IncF plasmids. Frontiers in

499 Microbiology, 2020. 11: p. 483.

500 13. Agyekum, A., et al., blaCTX-M-15 carried by IncF-type plasmids is the dominant

501 ESBL gene in Escherichia coli and Klebsiella pneumoniae at a hospital in Ghana. Diagnostic

502 microbiology and infectious disease, 2016. 84(4): p. 328-333.

503 14. Irrgang, A., et al., CTX-M-15-producing E. coli isolates from food products in

504 Germany are mainly associated with an IncF-type plasmid and belong to two predominant

505 clonal E. coli lineages. Frontiers in microbiology, 2017. 8: p. 2318.

506 15. Kopotsa, K., J. Osei Sekyere, and N.M. Mbelle, Plasmid evolution in

507 carbapenemase - producing Enterobacteriaceae: a review. Annals of the New York Academy

508 of Sciences, 2019. 1457(1): p. 61-91.

509 16. Rozwandowicz, M., et al., Plasmids carrying antimicrobial resistance genes in

510 Enterobacteriaceae. Journal of Antimicrobial Chemotherapy, 2018. 73(5): p. 1121-1137.

511 17. Shaw, L.P., et al., Niche and local geography shape the pangenome of wastewater-

512 and livestock-associated Enterobacteriaceae. bioRxiv, 2020: p. 2020.07.23.215756. 
513 18. Orlek, A., et al., Plasmid classification in an era of whole-genome sequencing:

514 application in studies of antibiotic resistance epidemiology. Frontiers in microbiology, 2017.

515 8: p. 182.

516 19. Blondel, V.D., et al., Fast unfolding of communities in large networks. Journal of

517 statistical mechanics: theory and experiment, 2008. 2008(10): p. P10008.

518 20. Yamashita, A., T. Sekizuka, and M. Kuroda, Characterization of antimicrobial

519 resistance dissemination across plasmid communities classified by network analysis.

520 Pathogens, 2014. 3(2): p. 356-376.

521 21. Branger, C., et al., Extended-spectrum $\beta$-lactamase-encoding genes are spreading on a

522 wide range of Escherichia coli plasmids existing prior to the use of third-generation

523 cephalosporins. Microbial genomics, 2018. 4(9).

524 22. Acman, M., et al., Large-scale network analysis captures biological features of

525 bacterial plasmids. bioRxiv, 2019: p. 785212.

526 23. Redondo-Salvo, S., et al., Pathways for horizontal gene transfer in bacteria revealed

527 by a global map of their plasmids. Nature Communications, 2020. 11(1): p. 1-13.

528 24. Jesus, T.F., et al., Plasmid ATLAS: plasmid visual analytics and identification in

529 high-throughput sequencing data. Nucleic acids research, 2019. 47(D1): p. D188-D194.

530 25. Almpanis, A., et al., Correlation between bacterial G+ C content, genome size and the

$531 \mathrm{G}+\mathrm{C}$ content of associated plasmids and bacteriophages. Microbial genomics, 2018. 4(4).

532 26. Dietel, A.-K., et al., Selective advantages favour high genomic AT-contents in

533 intracellular elements. PLoS genetics, 2019. 15(4): p. e1007778.

534 27. Ondov, B.D., et al., Mash: fast genome and metagenome distance estimation using

535 MinHash. Genome biology, 2016. 17(1): p. 132.

536 28. Traag, V.A., Faster unfolding of communities: Speeding up the Louvain algorithm.

537 Physical Review E, 2015. 92(3): p. 032801. 
538 29. Que, X., et al. Scalable community detection with the louvain algorithm. in 2015

539 IEEE International Parallel and Distributed Processing Symposium. 2015. IEEE.

540 30. De Maio, N., et al., Comparison of long-read sequencing technologies in the hybrid

541 assembly of complex bacterial genomes. Microbial genomics, 2019. 5(9).

542 31. Seeman, T., mlst.

$543 \quad 32 . \quad$ Wick, R.R., et al., Unicycler: resolving bacterial genome assemblies from short and

544 long sequencing reads. PLoS computational biology, 2017. 13(6): p. e1005595.

545 33. Galata, V., et al., PLSDB: a resource of complete bacterial plasmids. Nucleic acids

546 research, 2019. 47(D1): p. D195-D202.

547 34. Ondov, B.D., et al., Mash Screen: high-throughput sequence containment estimation

548 for genome discovery. Genome biology, 2019. 20(1): p. 232.

549 35. Robertson, J. and J.H. Nash, MOB-suite: software tools for clustering, reconstruction

550 and typing of plasmids from draft assemblies. Microbial genomics, 2018. 4(8).

551 36. Carattoli, A., et al., In silico detection and typing of plasmids using PlasmidFinder

552 and plasmid multilocus sequence typing. Antimicrobial agents and chemotherapy, 2014.

553 58(7): p. 3895-3903.

554 37. Rosenberg, A. and J. Hirschberg. V-measure: A conditional entropy-based external

555 cluster evaluation measure. in Proceedings of the 2007 joint conference on empirical methods

556 in natural language processing and computational natural language learning (EMNLP-

557 CoNLL). 2007.

558 38. Pedregosa, F., et al., Scikit-learn: Machine learning in Python. the Journal of machine

559 Learning research, 2011. 12: p. 2825-2830.

560 39. Seemann, T., Prokka: rapid prokaryotic genome annotation. Bioinformatics, 2014.

561 30(14): p. 2068-2069. 
562 40. Tonkin-Hill, G., et al., Producing Polished Prokaryotic Pangenomes with the Panaroo

563 Pipeline. BioRxiv, 2020.

564 41. Seemann, T., Abricate: mass screening of contigs for antimicrobial and virulence

565 genes. Department of Microbiology and Immunology, The University of Melbourne,

566 Melbourne, Australia. Available online: https://github. com/tseemann/abricate (accessed on

56728 February 2019), 2018.

568 42. Feldgarden, M., et al., Validating the AMRFinder tool and resistance gene database

569 by using antimicrobial resistance genotype-phenotype correlations in a collection of isolates.

570 Antimicrobial agents and chemotherapy, 2019. 63(11): p. e00483-19.

571 43. Sievers, F. and D.G. Higgins, Clustal Omega for making accurate alignments of many

572 protein sequences. Protein Science, 2018. 27(1): p. 135-145.

573 44. Didelot, X. and D.J. Wilson, ClonalFrameML: efficient inference of recombination in

574 whole bacterial genomes. PLoS computational biology, 2015. 11(2).

575 45. Yu, G., et al., ggtree: an R package for visualization and annotation of phylogenetic

576 trees with their covariates and other associated data. Methods in Ecology and Evolution,

$577 \quad 2017.8(1):$ p. 28-36.

578 46. Wickham, H., ggplot2: elegant graphics for data analysis. 2016: Springer.

579 47. Shannon, P., et al., Cytoscape: a software environment for integrated models of

580 biomolecular interaction networks. Genome research, 2003. 13(11): p. 2498-2504. 